American Journal of Applied Sciences 6 (6): 1186-1190, 2009

ISSN 1546-9239

(C) 2009 Science Publications

\title{
Alnus subcordata C.A.M. Cambium Cells Dynamics Along Transport Corridors in Hyrcanian Forests
}

\author{
${ }^{1}$ Aidin Parsakhoo, ${ }^{1}$ Hamid Jalilvand and ${ }^{2}$ Mehdi Sheikhi \\ ${ }^{1}$ Faculty of Natural Resources, Mazandaran University, Iran \\ ${ }^{2}$ Mazandaran University, Iran
}

\begin{abstract}
Problem statement: In this study, we considered transport corridors and sampling aspects to be the major indicators of ecological effects on Alder (Alnus subcordata) cambium cells dynamics. Approach: Thus, 240 cores were taken from forest-facing and road-facing trunk of Alder trees along Amre, Neka and Darab Kola transport corridors in hyrcanian Forests of Iran. Results showed that the roads corridor had significant effects on Alnus subcordata annual rings $(\mathrm{p}=0.04)$ and bark growth $(\mathrm{p}<0.0001)$. Results: In Darab Kola and Neka the bark thickness in road-facing aspect was significantly $(\mathrm{p}<0.05)$ more than forest-facing aspect because of consistency reaction to natural hazards. Annual rings width in adjacent stand was significantly $(\mathrm{p}<0.05)$ more than the rings width at both sides of trees trunk along transport corridors. Conclusion: Cambium cells dynamic diagram in production of annual rings indicated that the Alnus subcordata at commence of growth had been produced wide rings but in continuance the rings width reduced. This reduction was obviously for road-facing cores. Soil compaction, drainage structures, natural hazards and etc caused the thinner rings to be produced by cambium cells in road-facing aspect.
\end{abstract}

Key words: Alnus subcordata, cambium cells, annual rings, bark, transport corridor

\section{INTRODUCTION}

Transport corridors are becoming a focus of ecological research because of their distinctive structure, function and impact on surrounding ecosystems ${ }^{[12]}$. Forman and Alexander ${ }^{[8]}$ defined road corridors as pavement or unpaved plus managed roadsides and parallel vegetated strips along the roadside that extend up to the end of the right-of-way usually terminated by forest, lake, agricultural or other natural boundaries. Transportation corridors alters disturbance regimes in adjacent plant communities, both directly by creating gaps and by changing the plant composition ${ }^{[16]}$, and indirectly by altering environmental conditions such as light, soil moisture and bulk density ${ }^{[6,10,13,18]}$.

Alnus subcordata, Caucasian Alder, is a species in the family Betulaceae, native to temperate areas of Iran and the Caucasus. It is a deciduous tree growing to $15-25 \mathrm{~m}$ tall, closely related to the Italian Alder (A. cordata), with similar glossy green cordate leaves $5-15 \mathrm{~cm}$ long. The flowers are catkins, the male catkins very slender, $8-15 \mathrm{~cm}$ long, and the female catkins small, maturing into a woody cone-like fruit $2-3 \mathrm{~cm}$ long containing numerous small winged seeds. Alder tree is a stabilizer of nitrogen and often appear in the edge of the hyrcanian forest road after construction ${ }^{[11]}$.

Cambium is the thin growth layer that produces the phloem (outward towards the bark) and the xylem (inward towards the center) (Fig. 1). Damage to the cambium can weaken or kill a tree because new phloem and xylem will not be produced, preventing food and water transport. Common forms of damage are wounds by road construction and compaction. Growth cycles in

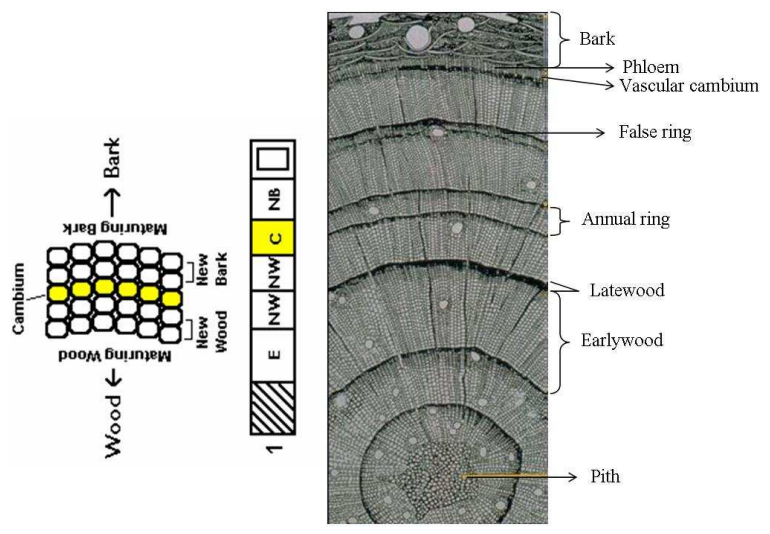

Fig. 1: Cross section of a conifer

Corresponding Author: Aidin Parsakhoo, Department of Forestry, Faculty of Natural Resources, Mazandaran University, Badeleh, Sari City, P.O. Box \#737, Mazandaran Province, Iran Tel: +98 1232221083 Fax: +98 1524222982 
trees are regulated by the seasonality of climate. In the temperate climate zones such as hyrcanian forest of Iran, tree-ring formation is limited to the vegetation period, which roughly lasts from spring to autumn. During the vegetation period, tree-ring formation is driven by a meristem called the vascular cambium. This tissue is located between the secondary xylem (wood) and the secondary phloem (bark) and divides off cells that will be become additional xylem and phloem ${ }^{[5,14]}$.

We carried out a research study to monitor effects of transport corridors on Alnus subcordata cambium cells dynamics in three sites of hyrcanian forests of Iran. In this study, we considered transport corridors and sampling aspects to be the major indicators of ecological effects on Alder rings and bark growth. Our aims were to (i) assess alder distribution along transport corridors; (ii) determine effects of forest roads on annual rings growth pattern; (iii) evaluate bark thickness for forest-facing and road-facing cores.

\section{MATERIALS AND METHODS}

Study area: The study sites are located in the northern forests of Iran and near the Caspian Sea (Fig. 2). The roads type in Amre and Darab Kola was unpaved and in Neka site was paved or asphalted. The height of forest sites at sea level starts from $260 \mathrm{~m}$ and continues to 883 $\mathrm{m}$. The average slope of forest fields is about $40 \%$ (Min. 5\% and Max. 80\%). The mean annual precipitation was ranged from $750-1110 \mathrm{~mm}$. Table 1 shows other characteristics of study areas. The experimental road section situation in all of the sites was from southeastern to northwestern.

Data collection: At each site, a sampling design consisted of two transects. First transect was established along transport corridor and the second transect was placed in the vicinity of the first transect into the forest stand. In each transect 10 circular plots with a size of $500 \mathrm{~m}^{2}$ were chosen. In each plot healthy and cylindrical Alder trees were numbered. Then, two Alder trees were selected with a simple randomize sampling method. The diameter of these trees was measured by means of the caliper and two cores were taken by means of the increment borer from two opposite sides of all trees (Forest-facing and road-facing cores) at standard breast height (Totally 240 cores were taken from three sites). Each core was dried, mounted and glued to a wooden core mount. Cores were sanded with sandpaper until the cellular structure of the tree rings was distinguishable. Variations in year to year ring widths for each core were recorded and then pooled to create a visual live-tree chronology of Alnus subcordata at each site.

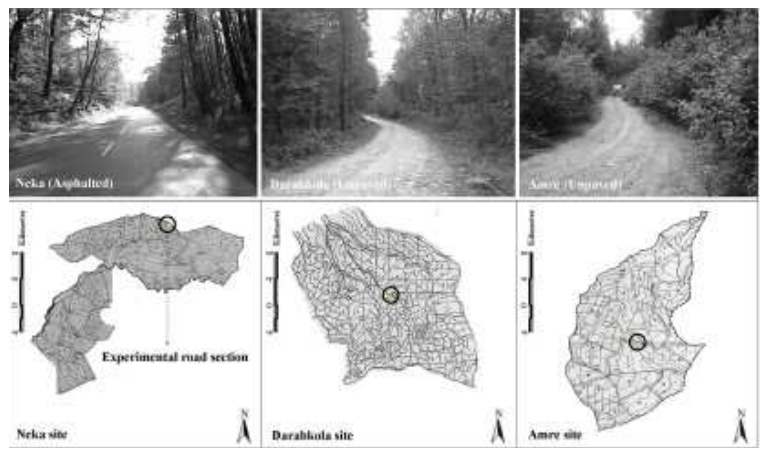

Fig. 2: Location of the study area in the north of Iran

Table 1: Characteristics of study sites

\begin{tabular}{|c|c|c|c|}
\hline Forest & Geographical position & $\begin{array}{l}\text { Temperature } \\
\text { range }\end{array}$ & Soil type \\
\hline Amre & $\begin{array}{l}53^{\circ} 55^{\prime}-53^{\circ} 85^{\prime} \mathrm{E} \mathrm{N} \\
27^{\circ}-36^{\prime \prime} 30^{\prime} 25^{\circ} 36\end{array}$ & $2-27.4^{\circ} \mathrm{C}$ & $\begin{array}{l}\text { Non development randzin } \\
\text { to washed randzin soil }\end{array}$ \\
\hline Neka & $\begin{array}{l}53^{\circ} 30^{\prime}-53^{\circ} 44^{\prime} \mathrm{E} \mathrm{N} \\
" 27^{\prime} 27^{\circ}-36^{\prime \prime} 77^{\prime} 23^{\circ} 36\end{array}$ & $0.4-28.4^{\circ} \mathrm{C}$ & $\begin{array}{l}\text { Brown and washed brown } \\
\text { forest soil with pseodoglay }\end{array}$ \\
\hline $\begin{array}{l}\text { Darab } \\
\text { Kola }\end{array}$ & $\begin{array}{l}52^{\circ} 14^{\prime} \text { to } 52^{\circ} 31^{\prime} \mathrm{E} \mathrm{N} \\
" 30^{\prime} 33^{\circ} 36^{\prime \prime} 20^{\prime} 33^{\circ} 36\end{array}$ & $-3-28^{\circ} \mathrm{C}$ & $\begin{array}{l}\text { Non development randzin } \\
\text { to washed randzin soil }\end{array}$ \\
\hline
\end{tabular}

Statistical analysis: All statistics were calculated with EXCEL and SAS software. Analysis of variance (ANOVA) was used to determine the effects of forest roads on annual rings growth and bark thickness. Wherever treatment effects were significant the Duncan's Multiple Range Test at probability level of $5 \%$ was carried out to compare the means.

\section{RESULTS AND DISCUSSION}

Alder distribution and density along transport corridor: In this study the Alnus subcordata (Alder) distribution and density was clearly related to distance from the transport corridors. At three sites the Alder was most prevalent within $0-10 \mathrm{~m}$ of the roadsides. In Amre the density of Alnus subcordata in the distance of 0-5 $\mathrm{m}$ was more than other distances from road edge. But in Darab Kola and Neka, Alder was most prevalent within the 5-10 m (Fig. 3).

Effects of transport corridor and sampling aspect: Analysis of variance showed that the roads corridor had significant effects on Alnus subcordata annual rings ( $\mathrm{p}$ $=0.04)$ and bark growth $(\mathrm{p}<0.0001)$. Also, the amount of bark thickness was significantly $(\mathrm{p}<0.0083)$ influenced by sampling aspects (forest-facing or roadfacing cores) (Table 2).

Bark and annual rings growth of Alnus subcordata: Table 3 summarizes vegetative characteristics of Alder trees and roads data for the three study areas. On 


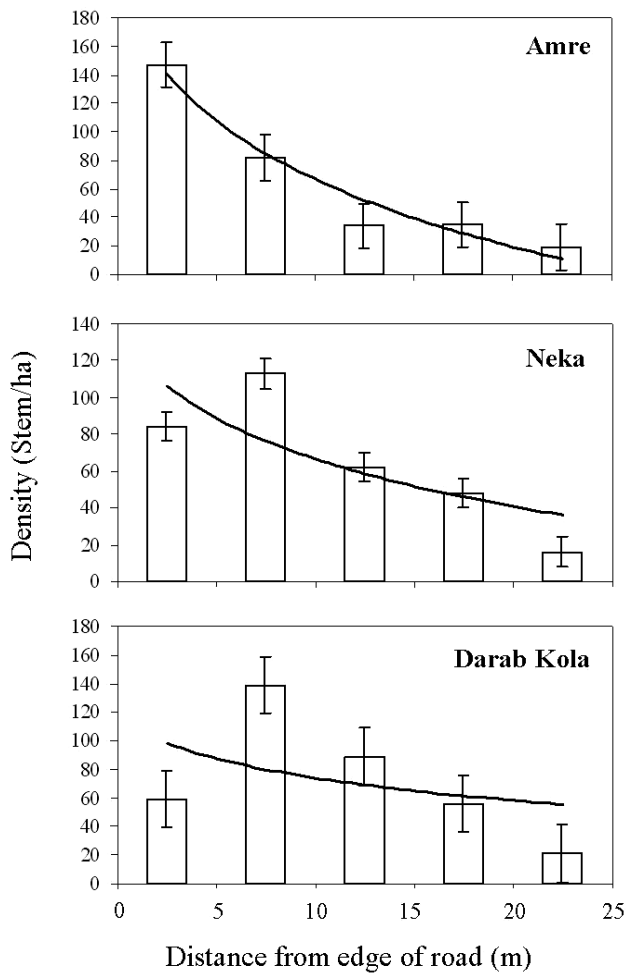

Fig. 3: Alder (Alnus subcordata) distribution and density along transport corridors

Table 2: ANOVA for Alnus subcordata growth parameters

\begin{tabular}{lllrrl}
\hline Parameter & Source & df & \multicolumn{1}{c}{ SS } & \multicolumn{1}{c}{ MS } & \multicolumn{1}{l}{ F } \\
\hline \multirow{3}{*}{ Tree rings width } & Road corridor & 2 & 7.19 & 3.59 & $3.31^{*}$ \\
& Sampling aspect & 1 & 1.19 & 1.19 & $1.10^{\text {ns }}$ \\
& Road. Aspect & 2 & 0.72 & 0.36 & $0.33^{\text {ns }}$ \\
Bark thickness & Road corridor & 2 & 103.73 & 51.87 & $14.10^{* * *}$ \\
& Sampling aspect & 1 & 26.32 & 26.32 & $7.15^{* *}$ \\
& Road. Aspect & 2 & 5.85 & 2.93 & $0.80^{\text {ns }}$ \\
\hline
\end{tabular}

Table 3: Description of the Alder trees and roads studied

\begin{tabular}{|c|c|c|c|c|c|}
\hline \multirow[b]{2}{*}{ Site } & \multicolumn{3}{|c|}{ Alnus subcordata (Alder) } & \multicolumn{2}{|l|}{ Road } \\
\hline & $\begin{array}{l}\mathrm{Dbh} \\
(\mathrm{cm})\end{array}$ & $\begin{array}{l}\text { Height } \\
\text { (m) }\end{array}$ & $\begin{array}{l}\text { Age } \\
\text { (year) }\end{array}$ & $\begin{array}{l}\text { Construction } \\
\text { time }\end{array}$ & Type \\
\hline$\overline{\text { Amre }}$ & 23.05 & 14.66 & 19 & 1985 & Unpaved \\
\hline Neka & 28.93 & 16.43 & 35 & 1970 & Asphalted \\
\hline Darab Kola & 27.38 & 15.21 & 34 & 1971 & Unpaved \\
\hline
\end{tabular}

average in each of the sites, bark thickness in roadfacing aspect of trees trunk which were located along transport corridors was significantly $(\mathrm{p}<0.05)$ more than the bark thickness in adjacent stand at both sampling aspects of trees. Also, annual rings width in adjacent stand was significantly $(\mathrm{p}<0.05)$ more than rings width at both sides of trees along transport corridors (Table 4).

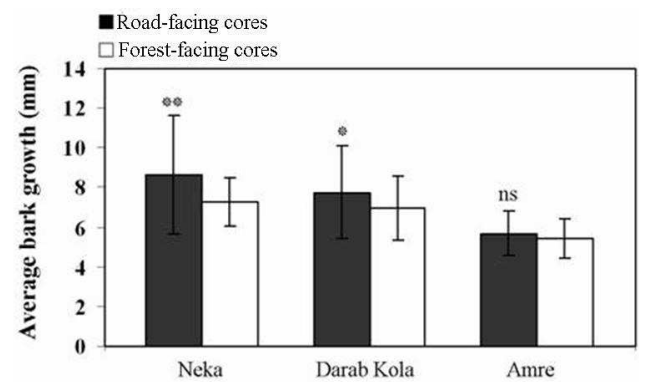

Fig. 4: Comparison of bark thickness for forest-facing and road-facing cores

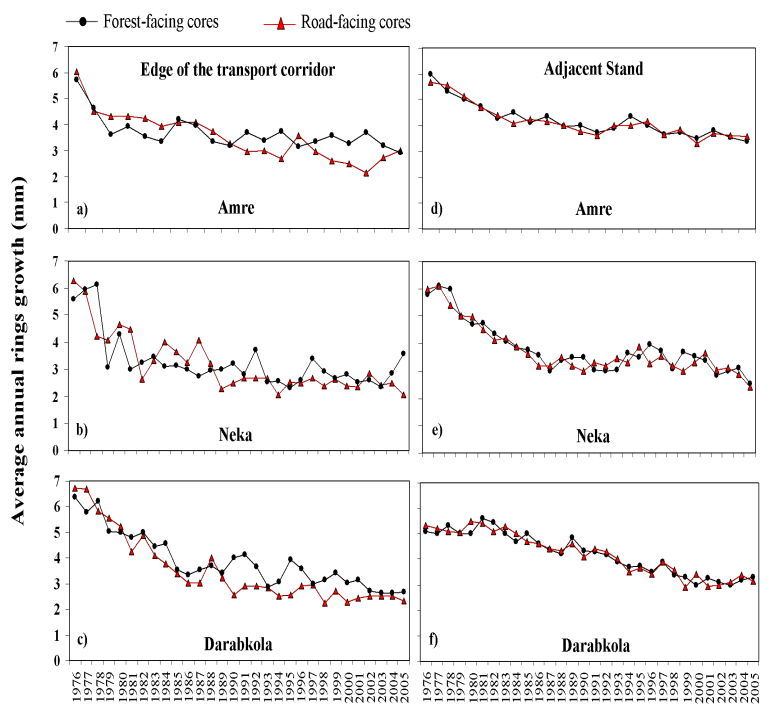

Fig. 5: Comparison of annual rings width for forestfacing and road-facing cores

Cambium cells dynamics along transport corridor: In Amre forest, there was no significant difference ( $>0.05)$ in bark thickness between the Forest-facing and road-facing cores, whereas in Darab Kola and Neka the bark thickness for road-facing cores was significantly $(p<0.05)$ more than forest-facing cores (Fig. 4). Cambium cells dynamic diagram in production of annual rings indicated that the Alnus subcordata at commence of growth had been produced wide rings but in continuance the rings width reduced. This reduction was obviously for road-facing cores (Fig. 5).

Our study has demonstrated that transport corridor influences Alder tree rings and bark growth. As Hosseini and Jalilvand ${ }^{[11]}$ have suggested, growth of Alnus subcordata rings in the forest-facing was greater than those which were in road-facing. They concluded that because of lack of forest road maintaining and repairing operations in suitable periods and tracks 
Am. J. Applied Sci., 6 (6): 1186-1190, 2009

Table 4: Comparison of bark and rings growth in the road edge and adjacent stand

\begin{tabular}{llllll}
\hline Site & Aspect & \multicolumn{2}{l}{ Bark growth $(\mathrm{mm})$} & & \multicolumn{2}{l}{ Annual rings growth $(\mathrm{mm})$} \\
& & - & Adjacent stand & Road edge & Adjacent stand \\
\hline Amre & Forest-facing & $5.44^{\mathrm{a}} \pm 0.07$ & $5.41^{\mathrm{a}} \pm 0.05$ & $3.67^{\mathrm{a}} \pm 0.06$ & $4.20^{\mathrm{b}} \pm 0.05$ \\
& Road-facing & $5.69^{\mathrm{a}} \pm 0.08$ & $5.37^{\mathrm{b}} \pm 0.06$ & $3.53^{\mathrm{a}} \pm 0.08$ & $4.16^{\mathrm{b}} \pm 0.04$ \\
Neka & Forest-facing & $7.30^{\mathrm{a}} \pm 0.13$ & $7.38^{\mathrm{a} \pm} 0.10$ & $3.27^{\mathrm{a}} \pm 0.06$ & $3.81^{\mathrm{b}} \pm 0.07$ \\
\multirow{2}{*}{ Darab Kola } & $8.63^{\mathrm{a}} \pm 0.16$ & $7.54^{\mathrm{b}} \pm 0.13$ & $3.19^{\mathrm{a}} \pm 0.04$ & $3.75^{\mathrm{b}} \pm 0.06$ \\
& Road-facing & $6.96^{\mathrm{a}} \pm 0.10$ & $7.03^{\mathrm{a}} \pm 0.14$ & $3.87^{\mathrm{a}} \pm 0.07$ & $4.21^{\mathrm{b}} \pm 0.05$ \\
& Forest-facing & $7.76^{\mathrm{a}} \pm 0.15$ & $7.24^{\mathrm{b}} \pm 0.12$ & $3.51^{\mathrm{a}} \pm 0.09$ & $4.21^{\mathrm{b}} \pm 0.09$ \\
\hline
\end{tabular}

In a row, means with the same letter(s) are not significantly different at 5\% level based on duncan test

traffic, the soil compaction increased and as result the tree growth around the roads decreased.

Bark protects both the living phloem and the vascular cambium of trees. For some tree species the bark has been observed to swell in the radial direction when heated by nearby flames, possibly providing additional protection from thermal injury ${ }^{[19]}$.

The results of this study showed that the amount of bark thickness was influenced by sampling aspects. In Darab Kola and Neka the bark thickness in road-facing was more than forest-facing. Butler et al. ${ }^{[4]}$ mentioned that bark swelling occurs in the mature bark of Douglas-fir and to a lesser degree in chestnut oak. Ponderosa pine and red maple did not exhibit statistically significant swelling, but rather a modest decrease in overall bark thickness with heating.

Cambium cells dynamic diagram in production of annual rings indicated that the Alnus subcordata at commence of growth had been produced wide rings but in continuance the rings width reduced. This reduction was obviously for road-facing cores. Altering the hydrologic regime of a wetland forest may result in changes in tree growth, as hydrology is a primary factor influencing the growth of wetland trees. Road construction, a common cause of altered hydrologic regimes, modified the hydrology of a permanently flooded southeastern backwater swamp and resulted in significantly higher water levels upstream of the road. Before road construction, annual growth patterns were similar at the two sites. Following construction, annual growth patterns in trees below the road were unchanged; however, growth of trees in the upstream area was accelerated for several years followed by a long-term decline ${ }^{[17,20]}$.

The tree growth effects resulting from soil damage from machine traffic and construction have varied with respect to soil type ${ }^{[1,15]}$, tree species, and severity of damage. Predicting long-term loss of productivity is considerably more complex than predicting growth losses in the compacted area since trees adjacent to the compacted area may grow slower or grow similarly or faster than trees in an undisturbed area ${ }^{[3,7,9]}$.

\section{CONCLUSION}

The ability to predict future growth patterns is essential to credible forest management planning ${ }^{[2]}$, and it is especially important in the process of permitting timber harvests where long-term projection is required. In this study the Alnus subcordata cambium cells produced thick bark in road-facing cores because of consistency reaction to natural hazards, whereas bark thickness of forest-facing cores was lower than opposite side. This result wasn't observed for trees which were located interior forest stands. For forest-facing cores and adjacent stand the action of Alnus subcordata cambium cells in annual rings growth pattern seems that be correlated to climate variables and hydrological condition (accessibility to water), but in the other side (Road-facing cores), rings growth at the beginning of the road construction time was affected by road characteristics such as degree of soil compaction, drainage structures, natural hazards and etc. Therefore these factors caused the thinner rings to be produced by cambium cells in road-facing cores.

\section{ACKNOWLEDJMENT}

The researchers are grateful to Nazanin Parsakhoo who typed numerous versions of this study with considerable technical expertise. The study of the researchers was supported in part by the faculty of natural resources.

\section{REFERENCES}

1. Angold, P.G., 1997. The impact of a road upon adjacent heathland vegetation: Effects on plant species composition. J. Applied Ecol., 34: 409-417. http://cat.inist.fr/?aModele=afficheN\&cpsidt=2673215

2. Barrett, T.M., L.S. Davis and F.G. Schurr, 1994. Using tree growth and yield simulators to create ecological yield tables for silvicultural prescriptions. West J. Applied For., 9: 91-94. http://www.fao.org/agris/search/display.do?f=./199 5/v2113/US9504335.xml;US9504335 
3. Bugg, R.L., C.S. Brown and J.H. Anderson, 1997. Restoring native perennial grasses to rural roadsides in the Sacramento Valley of California: Establishment and evaluation. Res. Ecol., 5: 214-228.

http://cat.inist.fr/?aModele $=$ afficheN $\&$ cpsidt $=2055148$

4. Butler, B.W., B.W. Webb, D. Jimenez, J.A. Reardon and J.L. Jones, 2005. Thermally induced bark swelling in four North American tree species. Can. J. For. Res., 35: 452-460. http://rparticle.web-

p.cisti.nrc.ca/rparticle/AbstractTemplateServlet?cal yLang=eng\&journal $=$ cjfr\&volume $=35 \&$ year $=2005$ \&issue $=2 \& m s n o=x 04-194$

5. Campbell, N.A., 1997. Biologie. Spektrum, Heidelberg, Berlin, Oxford, pp: 1482.

6. Delgado, J.D., N.L. Arroyo, J.R. Ar'evalo and J.M. Palacios, 2007. Edge effects of roads on temperature, light, canopy cover and canopy height in laurel and pine forests (Tenerife, Canary Islands). Landscape Urban Plan., 81: 328-340. http://www.cababstractsplus.org/abstracts/Abstract. aspx?AcNo=20073198769

7. Dykstra, P.R. and M.P. Curran, 2000. Tree growth on rehabilitated skid roads in southeast British Columbia. For. Ecol. Manage., 133: 145-156. http://cat.inist.fr/?aModele $=$ afficheN\&cpsidt $=1445354$

8. Forman, R.T.T. and L.E. Alexander, 1998. Roads and their major ecological effects. Annu. Rev. Ecol. Syst., 29: 207-231. DOI: 10.1146/annurev.ecolsys.29.1.207

9. Froehlich, H.A., 1979. Soil compaction from logging equipment: effects on growth of young ponderosa pine. J. Soil Water Conserv., 34: 276-278.

10. Hansen, M.J. and A.P. Clevenger, 2005. The influence of disturbance and habitat on the presence of non-native plant species along transport corridors. Biol Conserv., 125: 249-259. DOI: 10.1016/j.biocon.2005.03.024

11. Hosseini, S.A. and H. Jalilvand, 2007. Marginal effect of forest road on alder trees (Case study: Darab kola forest, mazandaran province, Iran). Pak. J. Biol. Sci., 10: 1766-1771. http://www.ncbi.nlm.nih.gov/pubmed/19086535

12. Jones, J.A., F.J. Swanson, D.C. Wemple and K.U. Syndel, 2000. Road effects on hydrology, geomorphology and disturbance patches in stream networks. Conserv. Biol., 14: 76-85. http://www.jstor.org/stable/2641906
13. Parendes, L.A. and J.A. Jones, 2000. Role of light availability and dispersal mechanisms in invasion of exotic plants roads and streams in the $\mathrm{H}$. J. Andrews Experimental Forest, Oregon. Conserv. Biol., 14: 64-75. DOI: 10.1046/j.15231739.2000.99089.x

14. Simon, T.M., D.C. Van Sickle, D.H. Kunishima and D.W. Jackson, 2003. Cambium cell stimulation from surgical release of the periosteum. J. Orthop. Res., 21: 470-480. http://www.ncbi.nlm.nih.gov/pubmed/12706020

15. Smith, R.B. and E.F. Wass, 1985. Some chemical and physical characteristics of skid roads and adjacent undisturbed soils. Inf. Rep. BC-X-261. Victoria, BC: Canadian Forest Service. Pac. For. Res. Centre, 28.

16. Sousa, W.P., 1984. The role of disturbance in natural communities. Annu. Rev. Ecol. Syst.., 15: 353-391. DOI: 10.1146/annurev.es.15.110184.002033

17. Stockton, C.W. and H.C. Fritts, 1973. Long-term reconstructions of water level changes for lake athabasca by analysis of tree rings. Water Res., 9: 1006-1025. DOI: $10.1111 / \mathrm{j} .1752-$ 1688.1973.tb05826.x

18. Watkins, R.Z., J. Chen and J. Pickens, 2003. Effects of forest roads on understory plants in a managed hardwood landscape. Conserv. Biol., 17: 411-419.

http://cat.inist.fr/?aModele $=$ afficheN\&cpsidt $=14746851$

19. Wilson, B.G. and E.T.F Witkowski, 2003. Seed banks, bark thickness and change in age and size structure of the African savanna tree, Burkea. Plant Ecol., 167: 151-162. DOI: 10.1023/A:1023999806577

20. Young, P.J., B.D. Keeland and R.R. Sharitz, 1994. Growth response of baldcypress (Taxodium distichum (L.) rich.) to an altered hydrologic regime. Am. Midl Nat., 133: 206-212. http://www.uga.edu/srel/Reprint/1951.htm 